\title{
Length-Weight Relationship and Condition Factor of Silver Catfish ( Chrysichthys nigrodigitatus) from the Lower Reaches of the New Calabar River Niger Delta
}

\author{
Abu Onisokyetu Monica Godwin, Agarin Onajefe Jennifer \\ Department of Fisheries and Aquaculture, Faculty of Agriculture, University of Port Harcourt, Choba, \\ Port Harcourt, Rivers State, Nigeria.
}

\begin{abstract}
The length-weight relationship and condition factor of silver catfish (Chrysichthys nigrodigitatus) from the lower reaches of the New Calabar River, Niger delta were evaluated between the months of July - November, 2015. The lowest length frequency (1) through the months was estimated for class $(81-85 \mathrm{~cm}),(91-95 \mathrm{~cm})$ and $(101-105 \mathrm{~cm})$. The modal length frequency (78) was estimated for class $(36-35 \mathrm{~cm})$. The highest number of catch measured was in the month of September with 124 samples and the lowest number of catch was in November with 15 samples. The smallest sample in terms of length was $18.5 \mathrm{~cm}$ and the longest was 101.0cm. In terms of weight: the largest fish weighed 13,000g, while the smallest was $150 \mathrm{~g}$. The lengthweight regression statistics was obtained using a software known as FISAT (FAO-ICLARM STOCK), with the mean regression coefficient or length exponent as $b=2.080$ with range of 1.9797-2.1460. The condition factor index value range from 0.85-1.98(mean $K=1.34$ ). Chrysichthys nigrodigitatus exhibited negative allometric growth all through the months. There is a strong association between the length and weight which was in a good condition.
\end{abstract}

Keywords: Fish, Length- Weight, River, Niger Delta

\section{INTRODUCTION}

Over the years fish has been identified as one of the most valuable source of protein to man and its importance cannot be overrated as it is easily digested and absorbed into the body(Akin rotimi et al., 2011). Fish is known to provide vital nutrient such as omega 6 oil and the cholesterol level is relatively very low. Chrysichthys nigrodigitatus commonly called silver catfish belongs to family of Claroteidae. They are of great ecological and economic importance as it plays a major role in the food chain and serves as food fish in Africa.(Abowei and Ezekiel, 2013). The capture fisheries resource worldwide is experiencing depletion of stock hence a lot of work is being carried out to give data on the status of some important fish species in other to regulate the fisheries. The silver catfish is widely distributed along the tropical and subtropical region. It is one of the most dominant species in the fish base region of Nigeria, mostly found along the Niger Delta region through the cross river region towards Cameroon. It also plays a prominent role in the ecology and fisheries of Nigeria (Erondu, 1990; Hart and Abowei, 2007; Francis and Sikoki, 2012).

The New Calabar River is characterised with different fish species and is mainly exploited by subsistent artisanal fishermen, that use traditionally fabricated gears such as drums, gill and cast nets etc. It serves a number of communities and a wide array of human and industrial developmental activities in the Niger Delta area (Ibim and Igbani, 2014). It is a freshwater at the Aluu and Isiokpo axis, and brackish at Choba axis and empties into the Atlantic at the southern tip of Bonny in the south. The fish species harvested by these fishermen mostly belong to the families Lutjanidae, Clupeidae more abundantly claroteidae (silver catfish) and Cichilidae (Tilapia).

The importance of Length weight relationship and condition factors in fisheries and fish biology cannot be overemphasized as they give an estimation of average weight of fish of a given length by establishing a mathematical relationship between them (King, 1996; Sarkar et al, 2008; Mir et al., 2012). Length -weight relationship and condition factor deals with the careful study of individual in a fish population which is an important aspect of fish population dynamics and fish biology. It is also useful when applied in fish stock assessment and they are applied in estimating the standing stock 
biomass and in comparing the ontogeny of a fish population from different regions (Akinrotimi et al., 2009; Ogamba et al., 2014).

Length-weight relationship allows the conversion of growth-in-length equations to growth-in-weight which is used in stock assessment models; an estimation of biomass from length observations; an estimate of the condition of the fish (Relative well-being of the fish) and also for useful comparison purpose. Fish can attain either isometric growth, negative allometric growth or positive allometric growth. Isometric growth is associated with no change of body shape as an organism grows. Negative allometric growth implies the fish becomes more slender as it increase in weight while positive allpometric growth implies the fish becomes relatively stouter or deeper-bodied as it increases in length (Sakar et al., 2013).

The condition factor is an estimation of the general well-being of fish (Abowei, 2006; Oribhabor $e t$ al., 2011). It is based on the hypothesis that heavier individuals of a given length are in better condition than less weightier fish (Begenal and Tesch 1978a; Abowei and Hart, 2008; Ogamba et al., 2014). Condition factors have been used as an index of growth and feeding intensity. This factor is a measure of various ecological and biological factors such as degree of fitness, gonad development and the suitability of the environment with regard to the feeding condition (Abowei, 2009). When condition factor value is higher it means that the fish has attained a better condition. This project therefore is an attempt to establish the well being of C.nigrodigitatus in New Calabar River, which of course will give us vital information on the continuous existence and well being of this fish in this River.

\section{MAterials AND Methods}

The fish samples used for the study was collected from the New Calabar River(lower region)located in River state, South of the Niger Delta Basin. The River is located between latitude: $44^{\circ} 25^{\prime} 0^{\prime \prime} \mathrm{N}$ and longitude: $7^{\circ} 16^{\prime} 0^{\prime \prime} \mathrm{E}$ (NDES, 2003).

The study was carried out in New Calabar, this is situated in the Niger Delta, being one of the major rivers that empty into the Atlantic Ocean. Receiving from ocean, the Atlantic water and hinterland freshwater places the river in a strategic position to serve many useful purpose such as means of livelihood, transportation, sand dredging, and pool of biodiversity to ensure food security and a sink for effluent discharge from food and construction companies (Francis and Elenwo, 2012).

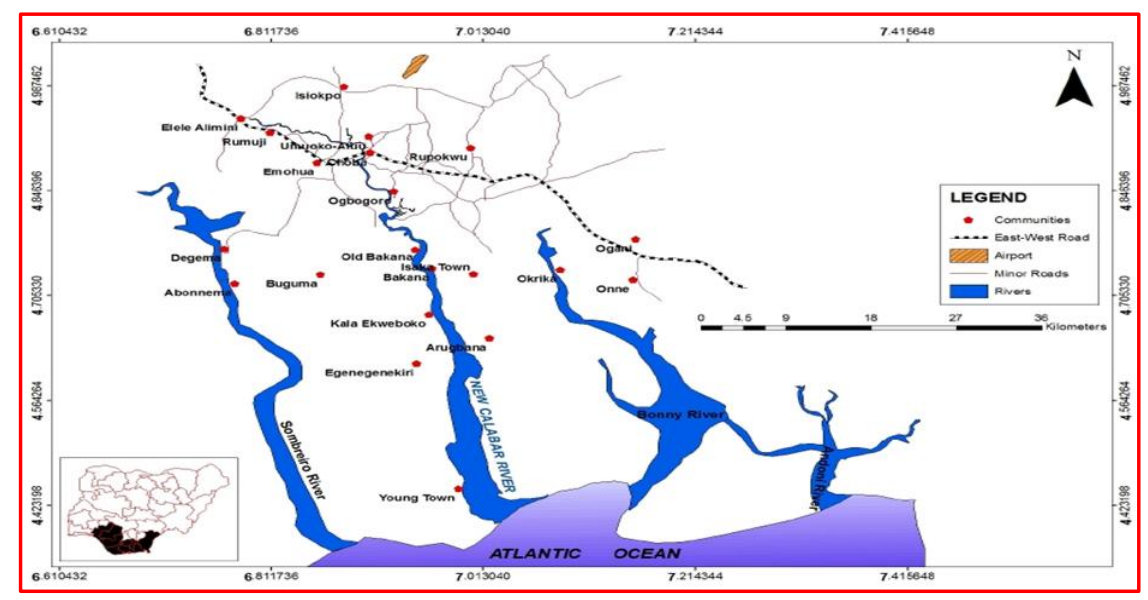

Fig1. Map of New Calabar River

\section{Fish Sampling}

Samples of Chrysichthys nigrodigitatus were collected from artisanal catches that were landed at the Onumiriahia landing site just before the Choba Bridge (Figure 1). The fish samples were gotten from the fish monger who buys all the catches from the fishermen.

\section{Experimental Procedure}

Samples of Chrysichthys nigrodigitatus were collected twice in July ( $2^{\text {nd }}$ and $4^{\text {th }}$ Saturday), twice weekly through the other months (Tuesdays and Saturdays from August to November). The length and weight of the total catch of the fish (Chrysichthys nigrodigitatus) was taken and recorded to the nearest centimetre and weight in grams. The total length(measured from the tip of the anterior most 
part of the snout to the tip of the caudal fin) was taken using a measuring board (which I constructed), then the weight of the fish was taken using a sensitive weighing balance with a load capacity of $1 \mathrm{Kg}$ and the values approximated to the nearest gram.

\section{Fishing Operation}

A fishing unit on the New Calabar River usually consists of fishing craft, gear and two fishers. The craft is mainly the dugout unmotorized canoe that is mechanically moved by paddle. Drums were used mainly to trap Chrysichthys nigrodigitatus.

\section{Data Analysis}

\section{Length Weight Relationship}

The length weight relationship was determined using this equation; Linear regression (Pauly,

1984). Linear regression which was incorporated into FISAT (FAO-ICLARM Stock Assessment Tool).

$$
\begin{aligned}
& \log _{10} \mathrm{~W}=a+b \log _{10} L \\
& \text { Where, } \\
& \mathrm{W}=\text { total wet weight of fish }(\mathrm{g}), \\
& \mathrm{L}=\text { Total length }(\mathrm{TL}) \text { of fish }(\mathrm{cm}), \\
& a=\text { constant (intercept), } \\
& b=\text { the length exponent (slope), } \\
& \log _{10} \mathrm{~W}=\mathrm{y} \\
& \log _{10} \mathrm{~L}=\mathrm{X} .
\end{aligned}
$$

The regression statistics was estimated by software known as FISAT (FAO-KLARM STOCK ASSESSMENT TOOL).

\section{The Fulton Condition Factor (K)}

The condition factor of fish was calculated using the formula according to Hile (1936)

$\mathrm{K}=\frac{W}{L_{3}} X 100$

Where:

$\mathrm{K}=$ Fulton condition factor

$\mathrm{W}=$ wet weight $(\mathrm{g})$ of the fish

$\mathrm{L}=$ total length $(\mathrm{cm})$ of the fish

\section{RESUlts}

A total of 329 fish specimen of Chrysichthys nigrodigitatus were measured for total length and weight for July to November. The shortest total length was recorded in the month of July as $8.60 \mathrm{~cm}$, while the longest total length was recorded in the month of November as $101 \mathrm{~cm}$. the least weight of $100 \mathrm{~g}$ was recorded in the month of July while the greatest individual weight was recorded in November as 13000g. (Table 1). The minimum and the maximum condition factor for C.nigrodigitatus for each month and the mean condition factor for every month of the research, the least condition factor of 0.85 was observed in the month of July, September and November while the highest condition factor of (1.98) was recorded in July, August and October. The mean condition factor for all 329 specimen were calculated as 1.34 (Table 2). Table 2 shows the condition factor for Chrysichthys nigrodigitatus from the New Calabar River with the highest value in the months of July, August and October while the least condition factor in the month of November. The result of regression statistics shows that C.nigrodigitatus has the highest b-value in the month of July and the lowest b-value in the month of November (Table 3). 
Table 1. Range of total length and wet weight of sampled C.nigrodigitatus from the New Calabar River.

\begin{tabular}{|l|l|l|l|}
\hline Month & Total length $(\mathrm{cm})$ & Wet weight $(\mathrm{g})$ & Population size $(\mathrm{n})$ \\
\hline July & $18.6-73.0$ & $100-6800$ & 57 \\
\hline August & $28.0-61.0$ & $250-4500$ & 49 \\
\hline September & $20.0-71.0$ & $150-7000$ & 124 \\
\hline October & $31.0-71.0$ & $350-6800$ & 83 \\
\hline November & $32.0-101.0$ & $350-13000$ & 16 \\
\hline
\end{tabular}

Table 2. Monthly condition factor of C. nigrodigitatus from the New Calabar River.

\begin{tabular}{|l|l|l|l|}
\hline Month & Mean & Minimum & Maximum \\
\hline July & $1.30 \pm 0.29$ & 0.85 & 1.98 \\
\hline August & $1.38 \pm 0.24$ & 0.93 & 1.98 \\
\hline September & $1.34 \pm 0.26$ & 0.85 & 1.98 \\
\hline October & $1.43 \pm 1.01$ & 1.01 & 1.98 \\
\hline November & $1.27 \pm 0.21$ & 0.85 & 1.62 \\
\hline
\end{tabular}

Table 3. Regression statistics for length-weight relationship of C.nigrodigitatus from New Calabar River.

\begin{tabular}{|l|l|l|l|l|l|}
\hline Month & a & b & r & \multicolumn{1}{|c|}{$\boldsymbol{r}^{\mathbf{2}}$} & growth type \\
\hline July & -0.5817 & 2.1460 & 0.9443 & 0.8917 & Negetive Allometric \\
\hline August & -0.3714 & 2.0593 & 0.9559 & 0.9137 & Negetive Allometric \\
\hline September & -0.5160 & 2.1388 & 0.9416 & 0.8866 & Negetive Allometric \\
\hline October & -0.3317 & 2.0811 & 0.9351 & 0.8743 & Negetive Allometric \\
\hline November & -0.1396 & 1.9797 & 0.9857 & 0.9716 & Negetive Allometric \\
\hline
\end{tabular}

$\mathrm{a}=$ correlation constant, $\mathrm{b}=$ regression constant or length exponent, $\mathrm{r}=$ correlation coefficient, $\mathrm{r} 2=$ square of the correlation coefficient, $\mathrm{b}$ mean $=2.08, \mathrm{~b}$ range $=1.9797-2.1460$.

\section{DisCUSSION}

Mean condition factor recorded in this study $(\mathrm{K}=1.34)$ agrees with the work of Francis and Elenwo (2012) who recorded mean of $K=1.31$, this indicates that the well being of this fish has not been altered despite environmental changes that may have occurred in that river between 2012 and 2015. While the range values they recorded $(0.40-1.93)$ varied from that of this work $(0.85-1.98)$ as recorded in table 4.2, which suggest that the fish are in better condition at the time of this study. Though, this can be attributed to the differences in the months of the study, (January-April, June, July) and (July-November). The highest value in the work of Francis and Elenwo (2012) referred to as previous study was in February with 1.93 while the highest $\mathrm{K}$ (condition factor) in this study was in the months of July, August, October with (1.98). This difference in values may be as a result of seasonal changes, being that the previous study was carried out in the early time of the year.

The condition factor recorded in this work also agrees with what other authors recorded in the lower New Calabar River, Chukwu and Deekae (2010) reported the condition factor of mudskipper (Periophthalamus barbarous) to be 1.214 for matured male and females, Ockyiya (2000) also reported the K factor of Channa channaas 0.955 for male, 1.169 for female and 1.072 for combined sex of this fish species. This indicates that the fish in the New Calabar River are in good condition because their K(condition factor) is greater than "1" though they may not be in perfect condition as the optimum $\mathrm{K}$ (condition factor) range for fresh fish body weight is 2.9-4.8 (Bagenal and Tesch, 1978a).

Considering the various condition factors reported for various fish species, especially the work done by Erondu (1997) who reported the K factor of male and female C.nigrodigitatus as 1.59 and 1.87 respectively in the lower New Calabar River. This difference may be as a result of changes that might have occurred over time such as seasonal change, degradation caused by oil explorative activities in the area. Some other causes like loss of aquatic vegetation can also bring about change in the well being of fish as noted by Offem et al (2008). However, significant changes have occurred over these years, this research work reveals that the C.nigrodigitatus from the Lower New Calabar River are still in good condition as the mean Condition factor $(\mathrm{K}=1.34)$ is greater that ' 1 '.

The length weight relationship was analysed using FiSAT (Fish Stock Assessment Tool). The regression coefficient (b) value was estimated for each month and the mean value was 2.080 with range of 1.9797-2.1460 (table 4.4). The result indicates that the fish exhibited a negative allometric 
growth pattern which means that the length and body weight of the fish did not grow in the same proportion, i.e. the fish grew faster in weight than in length and this is in agreement with the work done by Francis and Elenwo (2012) who also reported negative allometric growth(mean=2.00) in same New Calabar River from January to July. Also, research work on C. nigrodigitatus revealed an isometric growth in Andoni River a brackish water system in two consecutive years (Francis, 2003); such difference can point to a stable and more fitted nature of the brackish water environment for the development of C.nigrodigitatus. and Ofem et al .(2008) reported isometric and allometric growth at the upper and lower reaches of the Cross River estuary.

The variation of the ' $b$ ' value of the fish species of interest from other species of other waters could be as a result of food abundance, season, fishing pressures, sex, environmental degradation, habitat, diet and annual differences in environmental conditions (Bangenal and Tesch, 1978b; Abowei, 2006) It could also be attributed to a combination of the difference in the number of species, size of species, geographical location and season (Froese, 2006).Length weight relationship is influenced by many factors related to population, variability, sampling and estimation method. Sampling related factor include sample size, length distribution in the sample, type of length measurement while nutritional conditions account for intrinsic biological variability (Ricker, 1975).

\section{Conclusion}

The variation in the condition factor and parameters of the length weight of C.nigrodigitatus may be as a result of the differences in stage of maturity, sex, state of stomach fullness; differences in stock population, different growth rates at different stages of development and seasonal variation. However, since the Fulton condition factor $(\mathrm{K})$ reveals the well being of fish species, the New Calabar River appears to be well suited to the growth of C.nigrodigitatus when the high value of mean $\mathrm{K}$ is considered. Although it may not be the best but its considerable being that the $\mathrm{K}$ value is still above 1.It is observed that the condition of the fish in the River is gradually deteriorating, hence measures should be taken to reduce pollution impact on the water, so as to reduce fish mortality and improve the fishery.

\section{REFERENCES}

[1] Abowei, J.F.N and Hart A.I (2008). Artisanal fisheries characteristics of the fresh water reaches of the lower Nun River, Niger Delta, Nigeria. Journal of applied science and environmental management, 12:5-7.

[2] Abowei, J. F. N (2009), The Abundance Condition Factor and Length-Weight Relationship of Some Sardinellamaderensis (Jenyms, 1842) from Nkoro River, Niger Delta, Nigeria, Advanced Journal of Food Science and Technology, 1(1):65-70

[3] Abowei, J.F.N(2006). The condition factor length-weight relationship and abundance of Ilishaafricana( Block 1995) from Nkoro River, Niger Delta, Nigeria. Advanced journal of food science and technology, 2(1):6-11.

[4] Akinrotimi, O.A. Cliffe, P.T., \& Ibemere, I.F. (2011). Integration of rural aquaculture into small scale farming in Niger Delta region of Nigeria. Global Approaches to Extension Practice, 7(1), 43-48.

[5] Akinrotimi, O.A., Abu, O.M.G., Bekibele, D.O., George, O.S., \& Uedeme-Naa, B. (2009). Seasonal variation in length - weight relationship of the grey mullets, Liza falcipinnis and Liza grandiquamis from Buguma creek, Niger delta, Nigeria. International Journal of National and Applied Sciences, 5(3), $334-377$.

[6] Alfred-Ockiya, J. F (2000). The Length-Weight Relationship of Snake Head (Channachanna) from the Freshwater Swamps of Niger Delta, Nigeria. Journal of Aquatic Science, 15: 12-14

[7] Bagenal, J.B, Tesch F.W. (1978a). Methods for assessment of fish production in fresh waters, Oxford, Bladwen scientific publication. P-361.

[8] Bagenal, T.B and Tesch, A.T(1978b). Condition and growth pattern in fresh water habitat. Blackwell scientific publications, Oxford.

[9] Chukwu, K. O and Deekae S. N (2010), Length-Weight Relationship, Condition Factor and Size Composition of Periophthalmus barbarous (Linneaus 1766) In New Calabar River, Nigeria. Agriculture and Biological Journal of NorthAmerican. ISSN Print: 2151-7517 Online: 21517525, Doi:10.5251/abjna 2011.2.7.1069.1071 
[10] Davis, J.A and Hart, A.I (2001). Gill net selectively and fish abundance in the lower Nun River, Nigeria. Journal of Applied Science and environment management, 1; 13-19.

[11] Erondu E.S (1990) The diet of wild and pond cultured catfish(Chrysichthys nigrodigitatus) in mangrove swamps of the Niger Delta, Nigeria. J.Afr.Zool.104:367,374.

[12] Erondu E.S. (1997) Some aspect of the biology of Chrysichthys nigrodigitatusin the New Calabar River and its aquaculture potentials PhD Thesis, University of Nigeria Nsukka. Enugu state, 101-109.

[13] Francis A, and F.D Sikoki. Length weight relationship of fish species from the theAndonni River system, Niger Delta, Nigeria. Journal environment \& Ecology 25(2): 439-443, 2007.

[14] Francis, A and Elenwu U. (2012). Aspects of the biology of Chrysichthysnigrodigitatus (Lacepede: 1803) from the New Calabar River, Nigeria. International Journal Of Fisheries and Aquaculture 4(6):99-104

[15] Froese, R. (2006) Cube law, condition factor and length weight relationship: history, metanalysis and recommendations. Journal of Applied Ichthyology 22:241-253

[16] Hart A.I and Abowei J.F.N (2007). A study of the length weight relationship, abundance, condition factor and age of ten fish species from the upper Orashi River. Niger Delta , Nigeria. African journal of Applied Environmental Biology, 9.13-19.

[17] Hile R. (1936) Age and growth of Cisco leucicthyesartedi le suercur in the lake of north eartem highland S. Bull. U. S. Bur. Fish 48: 211-314

[18] Ibim, A. T and Igbani, F. (2014), Fish Species Composition, Diversity and Abundance of the Lower New Calabar River, River State. Journal of Aquatic Science 29 (1a): 59-71

[19] King R. P. (1996) Length-weight relationship of Nigeria. Freshwater fishes. Naga ICLARM Quarterly 19(3): 49-52.

[20] Mir J.I, U.K Sakar, A.K Dwivedi, O.P Gusain, A. Pal and J.K Jena. (2012). Pattern of intabasin variation in condition factor, relative condition factor and form factor of an Indian major Carp, Labeo rohita (Hamilton-Buchanan, 1822) in the Ganges Basin, India, Europe. J. Bio Sci, 4,126135(2012).

[21] NDES, (2003). Niger Delta Environmental Surveys. Environmental and socio economic characteristics of Niger Delta. NDES Bulletin, 2003.

[22] Offem B. O, Akegbejo O. Samsons Y., Isaac T.I (2008) Diet, size and reproductive biology of silver catfish Chrysichthysnigrodigitatus (Suilformes, bagridae) in cross river. int. J. Trop. Biol. 54(4): 1785-17799

[23] Ogamba E.N, J.F.N Abowei and A. Onugu (2014).. Length-weight relationship and condition factor of selected finfish species from Odi River, Niger Delta, Nigeria. Journal of Aquatic Science 29(1A):1-12

[24] Oribhabor B. J, Ogbeigbu, A. E and Udo, M. T. (2011), The Length-Weight Relationship of Brackish Water/Marine Fish Species Assemblage In Niger Delta Mangrove Creek, Nigeria. Current Research Journal of Biological Science 3(6): 616-621, 2011.

[25] Pauly D. (1984). Some simple methods for assessment of tropical fish stocks. FAO fish tech. Paper 243;53

[26] Sakar, U.K, P.K Deeper and R.S. Negi. (2008). Length- weight relationship of knifefishchitalachitala(Hamiton 1822) from the Ganga basin, India. J.Appl. icthyol.25, 232-233

[27] Sarkar, U. K., Khan, G. E., Dabas. A., Palhak, A. K., Mir, J. I., Rebello, J. C., Pal, A. and Singh, S. P (2013), Length-Weight Relationship And Condition Factor Of Selected Freshwater Fish Species Found In River Ganga, Gomti and Rapti. India Journal Of Environmental Biology, 23; 123-132. 


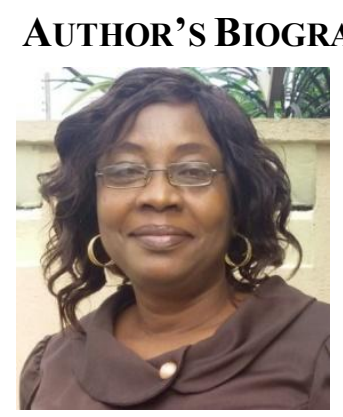

Dr. (Mrs.) O. M. G. Abu, is a Senior Lecturer in the Department of Fisheries, Faculty of Agriculture, University of Port Harcourt. She is a renowned expert, specializing in Aquaculture, Catfish Fingerling Production, Establishment of Fish Farms and Fish Nutrition and Processing. She is especially noted for her efforts in giving quality supervision to students in their research projects for good project work, improving learning and bringing the project to a good conclusion adding to knowledge. Dr. Abu has carried out several researches and has several publications in international and local journals covering diverse areas in fisheries. Dr Abu's current research and interests revolve around the Development of best aquaculture practices for healthy fish production and food safety. Her past roles include being the Former Director of Fisheries, Rivers State Agricultural Development Programme, Rivers State Nigeria, Personal Assistant to Honourable Commissioner for Agriculture, Rivers State Nigeria. Rivers State Facilitator for Fisheries in National Special Programme for Food Security, a World Bank Sponsored Project. Fisheries Consultant, International Institute for Tropical Agriculture (IITA) Onne, Managing Director SAMMANI CONSULTS, a capacity building outfit on agriculture and has trained many members of agriculture cooperatives. She has consulted for many fish farms including the famous CANABU FARMS in Rivers State. Dr. Abu is the founder of Divine Love Project, an organization that supports less privileged and motherless babies. 